\title{
Authentic leadership and behavioral integrity as drivers of staff nurses' commitment and work engagement
}

\author{
Amal Refaat Gab Allah* Rehab Abd Allah Nassar \\ Faculty of Nursing, Menoufia University, Menofia, Egypt
}

Received: December 13, 2020

DOI: $10.5430 /$ jnep.v11n6p26
Accepted: January 12, $2021 \quad$ Online Published: February 20, 2021

URL: https://doi.org/10.5430/jnep.v11n6p26

\begin{abstract}
Background and aim: Authentic leadership is relatively a new paradigm that emphasizes leaders' credibility. It can serve the healthcare organization to build an organizational culture that reinforces the healthcare worker in being committed and engaged in work. This study aimed to examine the effect of authentic leadership on staff nurses' affective organizational commitment and work engagement through examining the mediating role of behavioral integrity.

Methods: Study design: A descriptive correlational design was used in conducting this study. Setting: The study was conducted at two different hospitals, namely Menoufia University Hospital, and National Liver Institution, Egypt. Sampling: A Convenience sampling of two groups were selected; 64 front-line nurse managers and 320 staff nurses. Tools: Four instruments were used for collecting data; authentic leadership questionnaire, behavioral integrity scale, affective organizational commitment questionnaire, and Utrecht work engagement scale. Spearman correlation (r) and binary logistic regression analysis were used to achieve the study aim.

Results: Total behavioral integrity (BI) score was significantly correlated with total authentic leadership (AL) and two of its subscales (internalized moral perspective and balanced processing). Moreover, a significant positive correlation was revealed between the enactment of espoused values at one hand and total authentic leadership and its subscales except for self-awareness. Correlation analysis between BI and organizational commitment revealed a significant positive correlation between the two variables. A significant positive correlation was also found between the BI total and its subscales with work engagement total and its subscales.

Conclusions: This study supported the proposition that the relationship between authentic leadership and positive nurses' outcomes including affective commitment and work engagement is mediated by behavioral integrity.
\end{abstract}

Key Words: Authentic leadership, Behavioral integrity, Staff nurses, Commitment, Work engagement

\section{INTRODUCTION}

Worldwide, subsequent organizational failures associated with evident unethical behaviors drive the increasing attention on authentic leadership. Also, there is a current interest among scholars to validate existing authentic leadership theory so that a sound paradigm shift toward authentic lead- ership would be more defined and constructed. ${ }^{[1]}$ Authentic leadership is of most importance in the health care sectors where workers suffer from work overload, unsatisfactory salaries, and high job stress. ${ }^{[2]}$ Authentic leadership discusses the leader's ability to understand his/her strengths and weaknesses and regulate behaviors accordingly. Organiza-

*Correspondence: Amal Refaat Gab Allah; Email: amalrefaat54@yahoo.com; Address: Faculty of Nursing, Menoufia University, Menofia, Egypt. 
tional scholars had cited authentic leadership and a leader's behavioral integrity under the umbrella of positive organizational behaviors. ${ }^{[3]}$

Leadership behavior is an antecedent to perceptions of leader's behavioral integrity. Behavioral integrity denotes the perceptions followers hold toward their leader, how the leader keep on promises and endorse values he adopts. This concept is more comprehensive than is trust and usually assesses the perception of congruence between what the leaders say and do. Research evidence suggests that BI has a strong consequence on attitudes and performance of staff, managers and institutions as it has a mediating role between leaders behaviors and these outcomes. ${ }^{[4]}$

There are multiple similarities between the two variables but they are not the same. While authentic leadership is mainly in-ward focused and demonstrates leaders' credibility with oneself, behavioral integrity is mostly outward-focused reflecting how subordinates perceive alignment between their leaders' words, and actions. ${ }^{[5]}$ Self-aware leaders who express themselves openly and genuinely and truly share their own opinions with subordinates are referred to as authentic leaders. ${ }^{[6]}$ According to Leroy et al., ${ }^{[7]}$ authentic behavior is a way of communicating openly and non-defensively with others and one's self. All these attributes and behaviors empower authentic leaders to accelerate followers' trust in them. ${ }^{[8]}$

Furthermore, authentic leaders are better able to produce trusting relationships with their staff and help nurses become more satisfied with their jobs and more committed to their organizations. Staff nurses' commitment is a professional multidimensional construct that is defined as the identification with the health care organization's mission and work ethics. ${ }^{[9]}$ Numerous concepts are used as equal to "commitment" such as conscience, work ethic, propensity, and responsibility. ${ }^{[10]}$ Organizational commitment is defined by management experts as an attitude or a direction to an organization that relates the individual identity to an organization. ${ }^{[11]}$

Additionally, organizational commitment refers to the degree to which an individual identifies with and is involved in a particular organization. ${ }^{[12]}$ Organizational commitment is "the relative strength of an individual's identification with and involvement in a particular organization that is characterized by three factors: (1) a strong belief in and acceptance of the organization's goals and values, 2) a willingness to devote considerable effort on behalf of the organization, and 3) a strong desire to maintain membership in the organization". ${ }^{[13]}$ These three are called affective, continual, and assigning or normative commitment, respectively. ${ }^{[14]}$

Published by Sciedu Press
Besides, authentic leaders demonstrate an interest in followers and usually display honesty and reliability. ${ }^{[15]}$ Authentic leaders foster their followers' trust and augment their engagement at work. Also, effective nursing leadership has been positively linked to nurses' satisfaction, commitment, and engagement. ${ }^{[16]}$ Work engagement is a distinctive concept and involves an active emphasis when considering other behaviors within the workplace. Work engagement elicits alertness, excitement, elation, and enthusiasm. ${ }^{[17]}$

It consists of three domains; vigor, dedication, and absorption. Vigor indicates high levels of energy, mental flexibility, and willingness to devote effort to work. Dedication reflects active participation and feeling excited while demonstrating a willingness to face challenges at work and feeling pride in one's organization. Finally, absorption refers to concentration, engagement, and engrossment in the workplace. ${ }^{[18]}$ Hospitals where nurses work with a high degree of engagement, are likely to maintain high nurses' retention, quality of service, and patient satisfaction. ${ }^{[19]}$ Moreover, decreased burnout and turnover, in addition to better inter-professional collaboration and empowerment are positive outcomes of work engagement. ${ }^{[20]}$

The professional interpersonal relationship is expected to be developed between authentic leaders and employees and enhances employees' engagement levels and job satisfaction. ${ }^{[21]}$ So, the effect of authentic leadership on staff nurses' commitment and work engagement can be better understood by considering the mediating role of behavioral integrity. ${ }^{[7]}$ Behavioral integrity was proposed to be an important antecedent of employee affective organizational commitment. By delivering on promises, leaders high in behavioral integrity foster their followers' trust in them. Also, by conveying the same values through words and deeds consistently, the leader evidently and explicitly communicates what he or she truly values in work, therefore setting the basis of personal and social empathy of the follower with the leader. ${ }^{[3]}$

\subsection{The significance of the study}

Research studies about authentic leadership and behavioral integrity in the field of nursing management are in their impetus. Most people prefer working with individuals whose words can be relied on and can differentiate them from others who can't. The idea that a reliable leader must do what he says, lead by example, and deliver on promises is somewhat original. Many studies on leadership tackled that notion in some way, however, the paradigm has not yet taken the concentrated research attention it requires. Moreover, workers who are personally identified with their organization are more likely to work harder, encourage creativity, and participate in changes. Besides, hospitals with high employee 
engagement report satisfaction with job security, respectful treatment by employers, confidence in the management of senior leadership, and better trust in the organization. All this derived the researcher to conduct this study to examine the effect of authentic leadership on staff nurses' affective organizational commitment and work engagement through examining the mediating role of behavioral integrity.

\subsection{Purpose of the study}

The present study's purpose was to examine the effect of authentic leadership on staff nurses' affective organizational commitment and work engagement through examining the mediating role of behavioral integrity.

\subsection{Conceptual model and research hypotheses}

According to Avolio and Gardner, ${ }^{[22]}$ the association between authentic leadership and affective commitment could be explained in the light of the theory of social exchange and followers' identification with their leader. The open and non-defensive communication that authentic leaders follow during their interactions cultivates trust and shows leaders' readiness to become vulnerable. ${ }^{[23]}$ This mutual healthy rela- tionship represents the basis for personal and social identification between leaders and their subordinates. ${ }^{[24]}$ As followers begin to recognize, perceive and appreciate their leaders' interests, wishes, and values, personal identification occurs. Also, followers' perception of their leaders' role-position and as an organization's spokesperson sets the basis for social identification. Such identification will have a strong influence on follower's affective organizational commitment. ${ }^{[25]}$ In the light of the above theoretical propositions, it's expected that perceptions of behavioral integrity will intermediate the effect of authentic leadership on followers' affective organizational commitment and work engagement.

Based on the previous concepts, this study attempted to test the following hypotheses:

H1) Authentic leadership behavior is positively related to follower's perceptions of leader behavioral integrity.

H2) Behavioral integrity mediates the relationship between authentic leadership and follower affective organizational commitment.

H3) The effects of a leader's behavioral integrity on work engagement are mediated by follower affective organizational commitment.

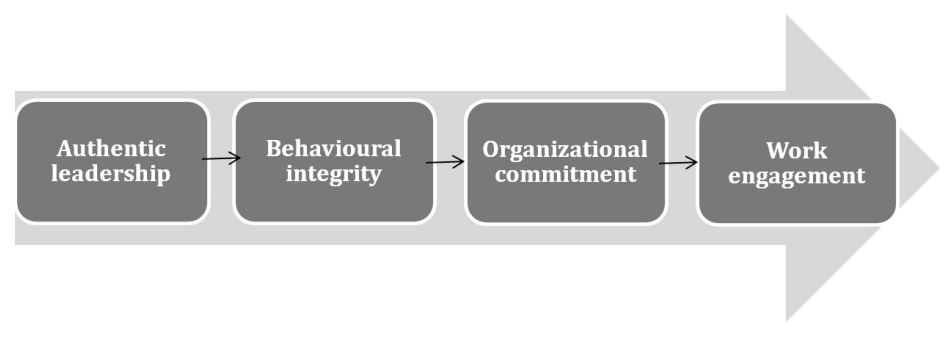

Figure 1. Proposed research model

\section{SUBJECTS AND METHODS}

\subsection{Research design}

A descriptive correlational design was used in conducting the current study.

\subsection{Study setting}

The study was conducted at critical care units at Menoufia University Hospital and National Liver Institution, Egypt.

\subsection{Subjects}

The study subjects consisted of two groups:

Group (1): The convenience sampling technique was employed to select all available first-line nurse managers at the previously mentioned setting. This group was composed of 64 nurse managers who were available at the time of the study and accept to participate in it.

Inclusion criteria for group (1): first-line nurse managers 28 who have at least one year of experience at their positions.

Group (2): A group of 320 staff nurses working at the same units of group (1) was selected by convenience sampling technique.

Inclusion criteria for group (2): the nurse must be working with the first line nurse manager at the same unit of work for at least one year.

\subsection{Instruments of data collection}

Data were collected using four different tools:

\section{Instrument (1): Authentic leadership questionnaire (ALQ)}

ALQ developed and validated by Walumbwa et al. ${ }^{[26]}$ It was utilized in this study to measure first-line managers' authentic leadership. It consists of four components: relational transparency (5 items), internalized moral perspective (4 items), 
balanced processing ( 3 items), and self-awareness (4 items). The managers were asked to rate themselves on a five-point Likert scale ranging from strongly agree " 5 " to strongly disagree " 1 ". The total score of the questionnaire was calculated by summing up the scores of all questionnaire items. A score of 64-80 indicates very high authentic leadership, $48-<64$ indicates high authentic leadership, $32-<8$ indicates low, whereas $16-<32$ indicates very low authentic leadership. ${ }^{[27]}$ The ALQ has demonstrated acceptable validity and reliability with Cronbach's a values of 0.92 (self-awareness), 0.87 (transparency), 0.76 (moral/ethical perspective), 0.81 (balanced processing) and 0.93 (overall) and item factor loadings ranging from $0.62-0.93$ were reported in the initial validation study. ${ }^{[26]}$

\section{Instrument (2): Behavioral integrity scale}

This instrument was developed by Simons and McLeanParks (2000) ${ }^{[28]}$ and reported by Simons Friedman, Liu, and McLean-Parks (2007) ${ }^{[29]}$ and used to measure staff nurses' perceived behavioral integrity of their managers. This scale includes (8) items divided into two subscales: one that focuses on the enactment of espoused values (four-item). The second focuses on promise-keeping behavior (four items). Items were measured on a five-point Likert scale ranging from completely agree " 5 " to completely disagree " 1 ". This scale has demonstrated consistently high reliabilities $(\alpha=$ 0.96). The two subscales were inter-correlated at $r=0.94 .^{[3]}$

\section{Instrument (3): Affective organizational commitment questionnaire}

Affective organizational commitment Questionnaire was developed by Meyer, Allen, and Smith (1993). ${ }^{[30]}$ Staff nurses were asked to respond to six items on a five-point Likert scale ranging from strongly agree " 5 " to strongly disagree "1". According to Meyer et al.'s (1993) model, an average score over 18 represents a positive answer to the perception of affective organizational commitment while scores equal to or less than 18 represent a negative answer. This questionnaire has demonstrated high reliability with Cronbach's $\alpha=$ 0.85 .

\section{Instrument (4): Utrecht work engagement scale (UWES- 9)}

This scale was developed by Schaufeli and Bakker (2003). ${ }^{[31]}$ It is composed of nine questions that examine the three aspects of work engagement: (a) vigor, (b) dedication, and (c) absorption. Three questions address each of the three aspects of work engagement. Participants responded on a 7-point scale ranging from 0 (never) to 6 (always). Higher overall scores indicate higher levels of work engagement. The validity and reliability of the UWES-9 were reviewed in a study conducted by Schaufeli and Bakker (2003). ${ }^{[31]}$ Cronbach's

Published by Sciedu Press $\alpha$ coefficient ranged between .80 and .90 and test-retest reliability was reported as high (Chapman, 2017). Scores for the UWES-9 and its subscales were calculated as follows, the total scores ranged from (0-56) and categorized as very high work engagement (48-54), high work engagement (36-47), average work engagement (24-35), low work engagement (12-23), and very low engagement (0-11).

\subsection{Pilot study}

A pilot study was conducted before starting the actual data collection. The pilot study aimed to test the clarity, relevance, and applicability of study questionnaires. Also to estimate the time required to fill the questionnaires. The nurse managers' questionnaire was administered to a sample of 8 managers who were not included in the main study sample. The time required for each manager to fill the questionnaire was estimated to be 10-15 minutes. No modifications were done after the pilot study. For the staff nurses' questionnaire, a pilot was conducted on a sample of 25 nurses. 15-20 minutes was the time required to fill in the staff nurses' questionnaire.

\subsection{Administrative and ethical aspects}

Written approval to conduct the study at the study setting was obtained from the medical and nursing directors of Menoufia University Hospital and Liver Institution. The objectives and procedures of the study were explained to the selected study participants and they were informed that their information will be treated with confidentiality. Oral consent was taken to protect participants' rights. They have the right to withdraw from the study at any point of time.

\subsection{Date collection procedures}

Data were collected for two months from the first of January, 2020 to the end of February, 2020. Official permission to conduct the study was issued from the Dean of the Faculty of Nursing, Menoufia University. Another permission to collect data was obtained from the directors of the two hospitals included in the study. The authentic leadership questionnaire was distributed among first-line nurse managers as a self-assessment questionnaire. The behavioral integrity questionnaire was distributed among staff nurses' group and they were asked to rate different dimensions of behavioral integrity of their leaders involved in the study (the first-line nurse managers). Affective organizational commitment and work engagement scales were also distributed among staff nurses group as self-administered questionnaires and the researchers were available for any clarifications.

\subsection{Statistical methods}

The data were collected, tabulated, and analyzed by SPSS (statistical package for social science) version 17.0 on IBM 
compatible computer (SPSS Inc., Chicago, IL, USA). Two types of statistics were done: Descriptive statistics: e.g. percentage $(\%)$, mean $(\bar{x})$ and standard deviation (SD). Analytic statistics: Spearman correlaton (r) and Binary logistic regression. Spearman correlation (r) was a nonparametric correlation test used to measure the association between each two of the measuring scales. Binary logistic regression analysis is a statistical process for estimating the relationships among variables. It focuses on the relationship between a dependent variable and one or more independent variables. It is used to predict the odds ratio. The odds are defined as the probability that a particular outcome to occur depending on the underlying factor. A $p$-value of less than .05 was considered significant.

\section{RESUltS}

Table 1 presents the socio-demographic characteristics of the study participants. The study included two groups; 64 of front-line nurse managers and 320 staff nurses. All the studied managers were females; also the majority of the staff nurses group (83.4\%) was females. As for age, the highest percentage of managers and nurses were in the age group between $30-<40(59.4 \%$ \& 57.5\%) respectively. All managers included had a bachelor's degree in nursing whereas the highest percentage of nurses $(34.4 \%$ ) had a technical nursing degree. Regarding the experience years, the majority of managers $(68.8 \%)$ had from $5-<10$ experience years and the highest percentage of nurses $(40.9 \%)$ had more than 10 years of experience. Equal percentages of managers were working in critical and inpatient units whereas the highest percentage of nurses $(53.8 \%)$ were working in inpatient departments.

Table 2 shows descriptive statistics of study variables. The highest percentage of studied nurse managers (68.8\%) rated themselves in the very high category of authentic leadership. Also, staff nurses had rated their nurse managers' behavioral integrity as high (25.14 \pm 2.26$)$. Regarding organizational commitment and work engagement, the highest percentage of staff nurses $(75 \%)$ had positive commitment whereas the majority of them $(96.9 \%)$ had average work engagement.

Table 1. Socio-demographic characteristics of the study participant (front-line nurse managers $(\mathrm{N}=64)$, staff nurses $(\mathrm{N}=$ 320)

\begin{tabular}{|c|c|c|c|c|}
\hline \multirow{2}{*}{ Socio-demographic characteristics } & \multicolumn{2}{|c|}{ Front-line nurse managers } & \multicolumn{2}{|c|}{ Staff nurses } \\
\hline & $\mathbf{N}$ & $\%$ & $\mathbf{N}$ & $\%$ \\
\hline \multicolumn{5}{|l|}{ Gender } \\
\hline Male & 0 & 0.00 & 53 & 16.6 \\
\hline Female & 64 & 100 & 267 & 83.4 \\
\hline \multicolumn{5}{|l|}{ Age } \\
\hline$<30$ & 0 & 0.00 & 71 & 22.2 \\
\hline $30-<40$ & 38 & 59.4 & 184 & 57.5 \\
\hline$\geq 40$ years & 26 & 40.6 & 65 & 30.3 \\
\hline \multicolumn{5}{|l|}{ Education } \\
\hline Bachelor degree in nursing & 64 & 100 & 107 & 33.4 \\
\hline Technical nursing degree & 0 & 0.00 & 110 & 34.4 \\
\hline Diploma in nursing & 0 & 0.00 & 103 & 32.2 \\
\hline \multicolumn{5}{|l|}{ Experience } \\
\hline$<5$ years & 1 & 1.6 & 65 & 20.3 \\
\hline $5-<10$ years & 44 & 68.8 & 124 & 38.8 \\
\hline$\geq 10$ years & 19 & 29.7 & 131 & 40.9 \\
\hline \multicolumn{5}{|l|}{ Units } \\
\hline Critical care unite & 32 & 50.0 & 148 & 46.3 \\
\hline Inpatient department & 32 & 50.0 & 172 & 53.8 \\
\hline
\end{tabular}

Table 3 shows the correlation among study variables. As evident in the table, the total BI score was significantly correlated with total authentic leadership and two of its subscales (internalized moral perspective and balanced processing) with $(p=.02, p=.02 \& p=.03)$ respectively. Moreover, a significant positive correlation was revealed between the enactment of espoused values at one hand and total AL and its subscales except for self-awareness. Correlation analysis between BI and organizational commitment revealed a significant positive correlation between total BI and its two subscales with organizational commitment $(p=.01, p=.01$ $\& p=.04)$ respectively. Furthermore, significant positive correlations were found between the BI total and its subscales with work engagement total and its subscales $(.005, .02, .01$ 
respectively).

Table 2. Descriptive statistics of study variables

\begin{tabular}{|c|c|}
\hline & $\begin{array}{l}\text { The studied manager } \\
N=64\end{array}$ \\
\hline \multicolumn{2}{|l|}{ ALQ components } \\
\hline \multicolumn{2}{|l|}{ Total ALQ } \\
\hline Very high & $44(68.8 \%)$ \\
\hline High & $20(31.2 \%)$ \\
\hline Low & $0(0.0 \%)$ \\
\hline Very low & $0(0.0 \%)$ \\
\hline Behavioral integrity subscales & $\begin{array}{l}\text { The studied staff nurses } \\
\mathrm{N}=320\end{array}$ \\
\hline \multicolumn{2}{|l|}{ Enactment of espoused values } \\
\hline Mean \pm SD (Min-max) & $12.77 \pm 1.31(9.5-15)$ \\
\hline \multicolumn{2}{|l|}{ Keeping behavior } \\
\hline Mean \pm SD (Min-max) & $12.37 \pm 1.17(8.8-14.6)$ \\
\hline \multicolumn{2}{|l|}{ Total } \\
\hline Mean \pm SD (Min-max) & $25.14 \pm 2.26(8.3-29)$ \\
\hline \multicolumn{2}{|l|}{ Utrecht Work Engagement Scale } \\
\hline \multicolumn{2}{|l|}{ Vigor } \\
\hline Mean \pm SD (Min-max) & $9.48 \pm 1.71(4.6-12)$ \\
\hline \multicolumn{2}{|l|}{ Dedication } \\
\hline Mean \pm SD (Min-max) & $11.89 \pm 1.67(7-14.4)$ \\
\hline \multicolumn{2}{|l|}{ Absorption } \\
\hline Mean \pm SD (Min-max) & $10.18 \pm 0.88(7.8-11.4)$ \\
\hline \multicolumn{2}{|l|}{ Organizational commitment } \\
\hline Mean \pm SD (Min-max) & $19.64 \pm 2.68(15.4-25.6)$ \\
\hline \multicolumn{2}{|l|}{ Organizational commitment } \\
\hline Positive & $48(75.0 \%)$ \\
\hline Negative & $16(25.0 \%)$ \\
\hline \multicolumn{2}{|l|}{ Total work engagement } \\
\hline Very high & $0(0.0 \%)$ \\
\hline High & $0(0.0 \%)$ \\
\hline Average & $62(96.9 \%)$ \\
\hline Low & $2(3.1 \%)$ \\
\hline
\end{tabular}

Table 4 presents the linear regression among study variables. Table 4 demonstrates that authentic leadership is an independent predictor for behavioral integrity with $p$ value .002 , standardized B 0.40 and $95 \%$ CI (0.20-0.84). Also, behavioral integrity was an independent predictor for organizational commitment with a $p$-value of .03 , standardized $\beta 0.013$, and 95\% CI (0.13-0.37) while organizational commitment was an independent predictor for work engagement with a $p$-value < .001 , standardized $\beta$ 0.44, and 95\% CI (0.24-0.80).

\section{Discussion}

Authentic leadership has been shown to impact followers' affective organizational commitment, performance, and organizational outcomes as it fosters confidence in and identification with the leader. ${ }^{[23]}$ Likewise, research on behavioral integrity explained its positive effect on follower's performance and affective organizational commitment. ${ }^{[32]}$ This study aimed to examine the effect of authentic leadership on staff nurses' affective organizational commitment and work engagement through examining the mediating role of behavioral integrity.

The highest percentage of studied nurse managers rated themselves in the very high category of authentic leadership. Also, staff nurses had rated their nurse managers' behavioral integrity as high. This congruence between managers' selfrating and the subordinate rating reflects managers' credibility, and being true to one's self. The highest percentage of staff nurses had positive commitment whereas the majority of them had average work engagement. In agreement, a study conducted by Darwish (2020) ${ }^{[33]}$ about shared governance; empowerment and work engagement revealed that staff nurses who participated in the study had average work engagement.

Table 3. Correlation among authentic leadership, behavioral integrity, organizational commitment, and work engagement

\begin{tabular}{|c|c|c|c|c|c|c|}
\hline \multirow{2}{*}{ Study variables } & \multicolumn{2}{|c|}{ Enactment of espoused values } & \multicolumn{2}{|c|}{ Keeping behavior } & \multicolumn{2}{|c|}{ Total behavioral integrity } \\
\hline & $\mathbf{R}$ & $p$ value & $\mathbf{R}$ & $p$ value & $\mathbf{R}$ & $p$ value \\
\hline \multicolumn{7}{|l|}{ Authentic leadership } \\
\hline Relational transparency & 0.30 & .02 & 0.09 & .49 & 0.10 & .43 \\
\hline Internalized moral perspective & 0.27 & .03 & 0.26 & .04 & 0.30 & .02 \\
\hline Balanced processing & 0.26 & .04 & 0.26 & .04 & 0.28 & .03 \\
\hline Self-awareness & 0.03 & .80 & 0.18 & .15 & 0.07 & .60 \\
\hline Total score & 0.35 & .005 & 0.27 & .03 & 0.30 & .02 \\
\hline Organizational commitment & 0.32 & .01 & 0.25 & .045 & 0.33 & .01 \\
\hline \multicolumn{7}{|l|}{ Work engagement } \\
\hline Vigor & 0.36 & .005 & 0.40 & .002 & 0.27 & .03 \\
\hline Dedication & 0.29 & .02 & 0.33 & .01 & 0.26 & .04 \\
\hline Absorption & 0.26 & .04 & 0.28 & .03 & 0.27 & .04 \\
\hline Total score & 0.31 & .02 & 0.32 & .01 & 0.35 & .005 \\
\hline
\end{tabular}


Table 4. Linear regression analysis for independent predictors of behavioral integrity, organizational commitment and work engagement

\begin{tabular}{|c|c|c|c|c|c|c|c|}
\hline & \multicolumn{7}{|c|}{ Behavioral integrity } \\
\hline & \multicolumn{2}{|c|}{ Unstandardized } & \multirow{2}{*}{$\begin{array}{l}\text { Standardized } \\
\text { Beta }\end{array}$} & \multirow{2}{*}{$t$ - test } & \multirow{2}{*}{$p$ value } & \multicolumn{2}{|c|}{$95.0 \%$ CI } \\
\hline & $\mathbf{B}$ & SE & & & & Lower & Upper \\
\hline (Constant) & -11.32 & 11.19 & & -1.01 & .32 & -33.71 & 11.07 \\
\hline Authentic leadership & 0.52 & 0.16 & 0.40 & 3.27 & .002 & 0.20 & 0.84 \\
\hline Organizational commitment & 0.12 & 0.13 & 0.11 & 0.94 & .35 & -0.14 & 0.38 \\
\hline \multirow[t]{4}{*}{ Work engagement } & 0.11 & 0.10 & 0.13 & 1.07 & .29 & -0.09 & 0.31 \\
\hline & \multicolumn{7}{|c|}{ Organizational commitment } \\
\hline & \multicolumn{2}{|c|}{ Unstandardized } & \multirow{2}{*}{$\begin{array}{l}\text { Standardized } \\
\text { Beta }\end{array}$} & \multirow{2}{*}{ t-test } & \multirow{2}{*}{$p$ value } & \multicolumn{2}{|c|}{$95 \% \mathrm{CI}$} \\
\hline & $\mathbf{B}$ & SE & & & & Lower & Upper \\
\hline (Constant) & 27.99 & 10.48 & & 2.67 & .01 & 7.02 & 48.97 \\
\hline Authenticated leadership & -0.23 & 0.17 & -0.19 & 1.38 & .17 & -0.57 & 0.11 \\
\hline Work engagement & 0.05 & 0.10 & 0.07 & 0.55 & .59 & -0.14 & 0.25 \\
\hline \multirow[t]{4}{*}{ Behavioral integrity } & 0.12 & 0.13 & 0.13 & 1.94 & .03 & -0.13 & 0.37 \\
\hline & \multicolumn{7}{|c|}{ Work engagement } \\
\hline & \multicolumn{2}{|c|}{ Unstandardized } & \multirow{2}{*}{$\begin{array}{l}\text { Standardized } \\
\text { Beta }\end{array}$} & \multirow{2}{*}{$t$-test } & \multirow{2}{*}{$p$ value } & \multicolumn{2}{|l|}{$95 \%$ CI } \\
\hline & B & SE & & & & Lower & Upper \\
\hline (Constant) & 21.05 & 6.82 & & 3.09 & .003 & 7.41 & 34.69 \\
\hline Authenticated leadership & 0.002 & 0.10 & 0.002 & 0.02 & .99 & -0.22 & 0.22 \\
\hline Organizational commitment & 0.52 & 0.14 & 0.44 & 3.70 & $<.001$ & 0.24 & 0.80 \\
\hline Behavioral integrity & 0.008 & 0.17 & 0.006 & 0.05 & .96 & -0.33 & 0.35 \\
\hline
\end{tabular}

Also, a study by Alfifi, Mahran, and Alabdulah (2019) ${ }^{[34]}$ about "Levels and Factors Influencing Work Engagement among Nurses in Najran Hospitals" concluded that the highest percentage of nurses $(49.1 \%)$ had an average level of work engagement. On contrary, Mason et al. (2014) ${ }^{[35]}$ reported a lower mean work engagement level than previous studies. Regarding affective commitment, a study by Luz and Oliveira $(2018)^{[36]}$ agrees with the current study results as participants had been found to have positive commitment. Total behavioral integrity score was significantly correlated with total authentic leadership and two of its subscales (internalized moral perspective and balanced processing). Moreover, a significant positive correlation was revealed between the enactment of espoused values at one hand and total authentic leadership and its subscales except for self-awareness. This led to the acceptance of the first study hypothesis.

The study results ascertained that leaders who are self-aware during interactions with followers engage in balanced processing, display transparency in making decisions, and commit to their held values are more likely to foster followers' experience of their behavioral integrity. In vein with this result, Leroy, Palanski, \& Simons (2012) ${ }^{[9]}$ concluded in their results that leaders who stay true to the self in their behavior, and use frank non-defensive communication with others, will be looked at as credible, keeping their promises, and walking the talk. Similarly, the relationship between authentic leadership and follower affective organizational commitment is fully mediated by the behavioral integrity of the leader. Authentic leadership foster follower identification with the organization because self-reliability, enables alignment between words and actions (behavioral integrity); consequently convince followers to trust their leader as a spokesperson of the organization. ${ }^{[9]}$

The second and third study hypotheses were also true. Correlation analysis between behavioral integrity and organizational commitment revealed a significant positive correlation between the two variables. Furthermore, significant positive correlations were found between the behavioral integrity total and its subscales with work engagement total and its subscales. In the same line, a study conducted by Swaina, Cao, and Gardner (2018) ${ }^{[37]}$ about "Six Sigma success: Looking through authentic leadership, and behavioral integrity theoretical lenses" argued that a leader who displays behavioral integrity can build trusting relationships with followers which enhance organizational commitment. Moreover, they indicated that, when the trusting relationship resulting from 
behavioral integrity is accompanied by clarity in direction, high work engagement will be the ultimate outcome.

Gatling et al. (2016) ${ }^{[38]}$ argued that there is a significant relationship between authentic leadership and organizational commitment. Furthermore, the systemic review conducted by Alilyyania, Wong and Cummings (2017) ${ }^{[39]}$ concluded that there are significant relationships between authentic leadership and multiple staff outcomes. Work engagement was significantly associated with authentic leadership in three out of four examined studies. Peus et al. (2012) ${ }^{[40]}$ found that followers' satisfaction with supervisor, organizational commitment and perceived team effectiveness were outcomes of authentic leadership. In the same line, Hmieleski et al. $(2012)^{[41]}$ found that shared authentic leadership has a positive indirect effect on firm performance. Rego et al. $(2012)^{[42]}$ find that authentic leadership predicts employees' creativity. Walumbwa et al. $(2010)^{[24]}$ found that authentic leadership was positively related to supervisor rated organizational citizenship behavior and work engagement.

In agreement with the current study, a study conducted by Leroy, Palanski, \& Simons (2012) ${ }^{[9]}$ revealed that authentic leadership and behavioral integrity are positively correlated, and behavioral integrity is more highly correlated with follower affective organizational commitment than is authentic leadership. The results demonstrated that authentic leadership is an independent predictor of behavioral integrity. Also, behavioral integrity was an independent predictor for organizational commitment. On contrary, in their systemic review about antecedents, mediators, and outcomes of authentic leadership in healthcare, Alilyyania, Wong \& Cummings $(2017)^{[38]}$ identified six main mediators other than behavioral integrity between authentic leadership and staff outcomes; empowerment, burnout, negative work behaviors, areas of work-life, trust and psychological capital.

In accordance, a study by Kannan-Narasimhan and Lawrence $(2012)^{[43]}$ about "Behavioral Integrity: How Leader Referents and Trust Matter to Workplace Outcomes" in India concluded that only senior management behavioral integrity predicted organizational commitment, while senior management behavioral integrity, supervisory behavioral integrity and supervisory trust predicted organizational cynicism. Regression analysis revealed that BI was not an independent predictor of work engagement but otherwise organizational commitment mediated the relationship between the two variables. On contrary, Prottas and Nummelin $(2018)^{[44]}$ concluded that BI was positively related to work engagement and that it had a direct effect on employee attitudes demonstrating higher work engagement.

Some researchers have studied work engagement as an an- tecedent to organizational commitment, whereas others have stated that organizational commitment has a direct effect on work engagement. A study by Zhang et al. (2015) ${ }^{[13]}$ exposed that work engagement mediated the partial negative effect of organizational commitment on turnover intention. On the other hand, Choi et al. $(2015)^{[45]}$ reported that affective organizational commitment played a partial mediating role between inclusive leadership and work engagement in Vietnam. In the same line, Rivkin et al. (2016) ${ }^{[46]}$ study in Germany demonstrated that affective commitment has a positive impact on improving work engagement. Also, results of Ibrahim and Falasi $(2014)^{[47]}$ revealed that affective commitment had a significant relationship with employee engagement in the United Arab Emirates.

\section{Conclusion}

The competitive work environment that nursing personnel works in requires that their leaders demonstrate authenticity by proposing clear values by which followers can identify with. This personal identification of the follower with the organization drives their willingness not only to promote a good image of the organization but also to adapt to changes and take initiative to improve the overall organizational health. The current study results supported the proposed research model, and hypotheses. Findings provide additional evidence for significant associations between authentic leadership, behavioral integrity, and staff nurses' positive outcomes; affective commitment and work engagement. Results concluded that authentic leadership was an independent predictor for behavioral integrity whereas behavioral integrity was an independent predictor for organizational commitment. Moreover, the organizational commitment was an independent predictor for work engagement. The use of self- assessment instruments and convenience sampling technique may limit the generalization of results.

\section{Implications for nursing management}

The findings provided support for the evidence of the link between authentic leadership, behavioral integrity, and positive staff outcomes. Furthermore, authentic leadership and behavioral integrity are critical factors for maintaining nurses' trust in their organizations. Health care organizations should provide training programs for nurse managers to improve their authentic leadership abilities and competencies. Health care leaders should work on dedicated resources to building an organizational culture that supports the demonstration of the key characteristics of authentic leadership, especially internalized moral perspective. Healthcare leaders should focus on building tools to evaluate for authentic leadership characteristics in the hiring and performance appraisal processes used in healthcare systems. Organizational and educational 
leaders must work on creating structures and curriculum that fosters building authentic leadership competencies early in nursing students to help new graduate nurses to translate their knowledge into leadership practices in clinical settings.

\section{ACKNOWLEDGements}

The researchers would like to thank all managers and nurses who participated in this study. Our deep heartily gratitude and thankfulness are submitted to our families for their kind support.

\section{CONFlicts of InTEREST Disclosure}

There were no conflicts of interest to declare.

\section{REFERENCES}

[1] Copeland MK. The impact of authentic, ethical, transformational leadership on leader effectiveness. Leader. Account. Ethics. 2016; 13(3): 79-97.

[2] Burke RJ, Koyuncu M, Fiksenbaum L, et al. Antecedents and consequences of work engagement among frontline employees in Turkish hotels. Journal of Transnational Management. 2013; 18: 191-203. https://doi.org/10.1080/15475778.2013.817243

[3] Simons T, Tomlinson EC, Leroy H. Research on behavioral integrity: A promising construct for positive organizational scholarship. In G. M. Spreitzer \& K. S. Cameron (Eds.). The Oxford handbook of positive organizational scholarship. New York, NY: Oxford University Press; 2011; 325-339.

[4] Gardner WL, Cogliser CC, Davis KM, et al. Authentic leadership: A review of literature and research agenda. The Leadership Quarterly. 2011; 22: 1120-1145. https://doi.org/10.1016/j.leaqua.2 011.09 .007

[5] Palanski ME, Yammarino FJ. Integrity and leadership: Clearing the conceptual confusion. European Management Journal. 2007; 25 171-184. https://doi.org/10.1016/j.emj . 2007.04.006

[6] Wei F, Li Y, Zhang Y, et al. The interactive effect of authentic leadership and leader competency on followers' job performance: The mediating role of work engagement. Journal of Business Ethics. 2018; 153(3): 763-773. https ://doi.org/10.1007/s10551-0 16-3379-0

[7] Leroy H, Anseel F, Gardner WL, et al. Authentic leadership, authentic followership, basic need satisfaction, and work role performance: A cross-level study. Journal of Management. 2015; 41: 1677-1697. https://doi.org/10.1177/0149206312457822

[8] Agote L, Aramburu N, Lines R. Authentic leadership Perception, trust in the leader, and followers' emotions in organizational change processes. The Journal of Applied Behavioral Science. 2016; 52(1): 35-63. https://doi .org/10.1177/0021886315617531

[9] Lorber M, Skela-Savič B. Factors Affecting Nurses' Organizational Commitment. Obzornik Zdravstvene nege. 2014; 48(4): 294-301

[10] Sanagoo A, Nikravesh M, Dabbaghi F. Organizational commitment from Nursing \& Midwifery Faculty members' perspective. Razi Journal of Medical Sciences. Razi Journal of Medical Sciences. 2016; 7(2): 105-113.

[11] Gautam T, Van Dick R, Wagner U. Organizational identification and organizational commitment: Distinct aspects of two related concepts. Asian Journal of Social Psychology. Wiley Online Library. 2012; 15(1): 244-255.

[12] Pien Lee S, Chitpakdee B, Chontawan Rb. Factors Predicting Organizational Commitment among Nurses in State Hospitals, Malaysia IMJM. 2011; 10(2): 21-28.

[13] Carman-Tobin Mary B. Organizational commitment among licensed practical nurses: exploring associations with empowerment, conflict and trust. PhD (Doctor of Philosophy) thesis, University of Iowa. 2011. Available from: http://ir.uiowa.edu/etd/2678

[14] Miandoab NY, Zare S, Salar AR, et al. The survey of the organizational commitment among Zahedan medical sciences staff in 2015. Indian Journal of Public Health Research and Development. 2016; 7(3): 293-297. https://doi.org/10.5958/0976-5506. 2016.00174 .1

[15] Jafari H, Mohammadian M, Pour DH. Organizational Health and its Relation to Organizational Commitment in Personnel of Selected Teaching Hospitals Affiliated with of Medical Sciences: 2011. Jundishapur Journal of Health Sciences, Ahvaz Jundishapur University of Medical Sciences. 2012; 4(1): 45-58.

[16] Akbari Haghighi F, Koohi Rostamkalaee Z, Pourreza A, et al. Surveying the employed Nurses' Organizational Commitment in Selected Tehran University of Medical Sciences Hospitals. Journal of Hospital. 2014; 13(2): 63-73.

[17] Hinojosa AS, McCauley KD, Randolph-Seng B, et al. Leader and follower attachment styles: Implications for authentic leaderfollower relationships. Leadership Quarterly. 2014; 25: 595-610. https://doi.org/10.1016/j. leaqua.2013.12.002

[18] Schaufeli WB. Engaging leadership in the job demands-resources model. Career Development International. 2015; 20: 446-463. https://doi.org/10.1108/CDI-02-2015-0025

[19] Sarti D. Job resources as antecedents of engagement at work: Evidence from a longterm care setting. Human Resource Development Quarterly. 2014; 25(2): 213-237.https://doi.org/10.1002/hr dq. 21189

[20] Dempsey C, Reilly B. Nurse Engagement: What are the Contributing Factors for Success. OJIN: The Online Journal of Issues in Nursing. 2016; 21(1).

[21] Giallonardo L, Wong C, Iwasiw C. Authentic leadership of preceptors: predictor of new graduate nurses' work engagement and job satisfaction. Journal of Nursing Management. 2010; 18: 993-1003. PMid:21073571 https://doi.org/10.1111/j.1365-2834.20 $10.01126 . x$

[22] Avolio BJ, Gardner WL. Authentic leadership development: Getting to the root of positive forms of leadership. The Leadership Quarterly. 2005; 16: 315-338. https://doi .org/10.1016/j. leaqua. 200 5.03 .001

[23] Walumbwa FO, Luthans F, Avey J, et al. Authentically leading groups: The mediating role of positivity and trust. Journal of Organizational Behavior. 2011; 34: 89-126.

[24] Walumbwa FO, Wang P, Wang H, et al. Psychological processes linking authentic leadership to follower behaviors. The Leadership Quarterly. 2010; 21: 901-914.https://doi.org/10.1016/j.le aqua.2010.07.015

[25] Avolio BJ, Gardner WL, Walumbwa FO, et al. Unlocking the mask: A look at the process by which authentic leaders impact follower atti- 
tudes and behaviors. The Leadership Quarterly. 2004; 15: 801-823. https://doi.org/10.1016/j.leaqua.2004.09.003

[26] Walumbwa FO, Avolio BJ, Gardner WL, et al. Authentic leadership: Development and validation of a theory based measure. Journal of Management. 2008; 34(1): 89-126. https://doi.org/10.1177/ 0149206307308913

[27] Northouse PG. Leadership: Theory and practice. 5th ed. Thousand Oaks, CA: Sage Publications; 2010

[28] Simons TL, McLean-Parks J. The sequential impact of behavior integrity on trust, commitment, discretionary service behavior, customer satisfaction, and profitability. Paper presented at the annual Academy of Management Conference. 2000.

[29] Simons TL, Friedman R, Liu LA, et al. Racial differences in sensitivity to behavioral integrity: Attitudinal consequences, in-group effects, and "trickle down" among black and non-black employees. Journal of Applied Psychology. 2007; 92: 650-665. PMid:17484548 https://doi.org/10.1037/0021-9010.92.3.650

[30] Meyer JP, Allen NJ, Smith CA. Commitment to organizations and ocupations: extension and test of a three-component conceptualization. Journal of Applied Psychology. 1993; 78(4): 538-551. https://doi.org/10.1037/0021-9010.78.4.538

[31] Schaufeli WB, Bakker A. UWES: Utrecht Work Engagement Scale, preliminary manual. 2003. Available from: http://www . beanmanaged.com/doc/pdf/arnoldbakker /articles/articles_arnold_bakker_87.pdf

[32] Palanski ME, Kahai SS, Yammarino FJ. Team virtues and performance: An examination of transparency, behavioral integrity, and trust. Journal of Business Ethics. 2011; 99: 201-216. https: //doi.org/10.1007/s10551-010-0650-7

[33] Darwish S. The relationship among shared governance, nurses' empowerment and work engagement at Menoufia University Hospital. Faculty of Nursing, Menoufia University. 2020.

[34] Alfifi, Mahran, Alabdulah. Levels and Factors Influencing Work Engagement among Nurses in Najran Hospitals. IOSR Journal of Nursing and Health Science (IOSR-JNHS), 2019; 8(2): 52-55.

[35] Mason VM, Leslie G, Clark K, et al. Compassion fatigue, moral distress, and work engagement in surgical intensive care unit trauma nurses: A pilot study. Dimensions of Critical Care Nursing. 2014; 33(4): 215-225. PMid:24895952 https://doi .org/10.1097/DC C. 0000000000000056

[36] Luz C, Oliveira S. Organizational commitment, job satisfaction and their possible influences on intent to turnover. Revista de Gestão. 2018; 25(1): 84-101. https://doi.org/10.1108/REGE-12-2 017-008
[37] Swaina A, Cao Q, Gardner W. Six Sigma success: Looking through authentic leadership and behavioral integrity theoretical lenses. Operations Research Perspectives. 2018; 5: 120-132. https://doi.or g/10.1016/j.orp. 2018.04.001

[38] Gatling A, Kang HJA, Kim JS. The effects of authentic leadership and organizational commitment on turnover intention. Leadersh. Organ. Dev. J. 2016; 37(2): 181-199. http://dx.doi.org/10.1108 /LODJ-05-2014-0090

[39] Alilyyania B, Wong C, Cummings G. Antecedents, mediators, and outcomes of authentic leadership in healthcare: A systematic review. International Journal of Nursing Studies. 2018; 83: 34-64. PMid:29684833 https://doi.org/10.1016/j.ijnurstu. 201 8.04 .001

[40] Peus C, Wesche JS, Streicher B, et al. Authentic leadership: An empirical test of its antecedents, consequences, and mediating mechanisms. Journal of Business Ethics. 2012; 107(3): 331-348. https://doi.org/10.1007/s10551-011-1042-3

[41] Hmieleski, Cole, Baron. Shared Authentic Leadership and New Venture Performance. Journal of Management. 2012; 38(5): 1476-1499. https://doi.org/10.1177/0149206311415419

[42] Rego A, Marques C, Cunha M. 2012. Authentic leadership promoting employees' psychological capital and creativity. Journal of Business Research. 2012; 65(3): 429-437. https://doi.org/10.1016/j. jbusres.2011.10.003

[43] Kannan-Narasimhan R, Lawrence B. Behavioral Integrity: How Leader Referents and Trust Matter to Workplace Outcomes. J Bus Ethics. 2012; 63(6): 111, 165-178. https://doi.org/10.1007/ s10551-011-1199-9

[44] Prottas, Nummelin. Behavioral Integrity, Engagement, Organizational Citizenship Behavior, and Service Quality in a Healthcare Setting. Journal of healthcare management/American College of Healthcare Executives. 2018; 63(6): 410-424. PMid:30418370 https://doi.org/10.1097/JHM-D-17-00134

[45] Choi SB, Tran TBH, Park BI. Inclusive leadership and work engagement: Mediating roles of affective organizational commitment and creativity. Social Behavior and Personality. 2015; 43: 931-944. https://doi.org/10.2224/sbp.2015.43.6.931

[46] Rivkin W, Diestel S, Schmidt KH. Which daily experiences can foster wellbeing at work? A diary study on the interplay between flow experiences, affective commitment, and self-control demands. Journal of Occupational Health Psychology. 2016; 16: 1-13.

[47] Ibrahim M, Falasi SA. Employee loyalty and engagement in UAE public sector. Employee Relations. 2014; 36: 562-582. https: //doi.org/10.1108/ER-07-2013-0098 